\title{
Adherencia al Tratamiento de la Anemia con Fumarato Ferroso Microencapsulado
}

\author{
C. CINTHYA URQUIDI B. ${ }^{1}$, HÉCTOR MEJÍA S. ${ }^{2}$, CLAUDIA VERA A. ${ }^{3}$ \\ 1. Médico Epidemiólogo. \\ 2. Pediatra. Hospital del Niño "Dr. Ovidio Aliaga U." La Paz, Bolivia. \\ 3. Médico Cirujano. Centro de Iniciativa para el Desarrollo y Promoción en Salud.
}

\begin{abstract}
Adherence to Treatment of Anemia with Microencapsulated Ferrous Fumarate
\end{abstract}

Objective: To evaluate the adherence to treatment of anemia through the percentage of response with ferrous fumarate, in comparison to ferrous sulfate drops after two months of treatment. Study Design: randomized controlled clinical trial. Intervention: ferrous sulfate drops and microencapsulated ferrous fumarate sprinkles. Methods: 128 Children (age 6-24 months) were enrolled and randomized to ferrous sulfate drops group or ferrous fumarate group. Capillary blood samples taken at the baseline and final visits were obtained from a finger prick in order to asses hemoglobin values. Compliance was also measured. Results: Successful treatment of anemia (hemoglobin $>13,6 \mathrm{~g} / \mathrm{dl}$ ) occurred in $54 \%$ of the sprinkles group and in $22 \%$ of the drops group $(\mathrm{p}<0,05)$. The positive response to treatment was higher in the experimental group $(91 \%)$ than the control group $(71 \%)(p<0,05)$. The rate of compliance was $55 \%$ in the control group and $76 \%$ in the experimental group. The mean hemoglobin levels increases significantly in each group from baseline to the final visit. Conclusion: The use of microencapsulated ferrous fumarate increased the adherence to treatment and reduced the rates of anemia significantly in high risk pediatric population. The implementation of this new intervention by health programs will enhance over $33 \%$ the benefits of supplementation.

(Key words: Anemia, iron deficiency, adherence, ferrous sulfate, ferrous fumarate).

Rev. Soc. Bol. Ped. 2007; 46 (1): 3-11

\section{RESUMEN}

Objetivos: Evaluar según el porcentaje de respuesta, la adherencia al tratamiento de la anemia con microgránulos de fumarato ferroso. Diseño: Ensayo clínico aleatorio controlado. Intervención: gotas de sulfato ferroso y microgránulos de fumarato ferroso. Métodos: 124 niños con valores de hemoglobina menores a $13,7 \mathrm{~g} / \mathrm{dL}$ y de 6 a 24 meses de edad ingresaron al estudio, fueron asignados en forma aleatoria a dos grupos, el grupo control con sulfato ferroso y el grupo experimental de los microgránulos con fumarato ferroso. Se midieron los niveles de hemoglobina antes y después del tratamiento y otras variables

Correspondencia a:

Dra. Cinthya Urquidi B.

E-mail: claudiacinthya@gmail.com 
de cumplimiento. Resultados: El porcentaje de niños que pasaron al estado no anémico en el grupo fumarato ferroso fue de $54 \%$ y en el grupo control $22 \%(\mathrm{p}<0,05)$. El porcentaje de respuesta positiva al tratamiento en el grupo fumarato fue de $91 \%$ y en el grupo control del $71 \%(p<0,05)$. La media de hemoglobina aumento significativamente en ambos grupos, siendo la hemoglobina final media en el grupo experimental de $13,5 \mathrm{~g} / \mathrm{dL}$ y de $12,6 \mathrm{~g} / \mathrm{dL}$ en el control $(\mathrm{p}<0,05)$. El porcentaje de cumplimento fue significativamente mayor en el grupo experimental $(78 \%)$ que en el control $(55 \%)(p<0,05)$. Conclusiones: El uso del fumarato ferroso microencapsulado, produce una reducción significativa de la prevalencia de anemia en una población pediátrica de alto riesgo por presentar mejor adherencia a este. La aplicación de la nueva intervención en los programas de salud, aumentaría en un 33\% los beneficios obtenidos por el nuevo suplemento.

(Palabras clave: Anemia, deficiencia de hierro, adherencia, fumarato ferroso).

Rev. Soc. Bol. Ped. 2007; 46 (1): 3-11

ESTE TRABAJO LO PUEDE ENCONTRAR EN EXTENSO EN WWW.SCIELO.CL 